\title{
Liquidity Expectation, Financing Ability and Credit Rating: Evidence from China
}

\author{
Shan Tian ${ }^{1}$, Song Zhu' ${ }^{2}$, Bo Liu ${ }^{3}$ \\ ${ }^{1}$ Department of Accounting, Tourism and Culture College of Yunnan University, Yunnan, China \\ ${ }^{2}$ Business School, Beijing Normal University, Beijing, China \\ ${ }^{3}$ China Sinopharm International Corporation, Beijing, China \\ Email: ts0415@163.com, zhusong@bnu.edul.cn, liubo8218@sina.com
}

Received June 16, 2012; revised July 15, 2012; accepted July 25, 2012

\begin{abstract}
Sovereign Credit Ratings of many countries and credit rating of dozens of firms has been downgraded since the latest financial crisis. However in China short-term financing market, the credit rating seems to show a counter-cyclical phenomenon. We find that when the market and the economy upsurge, the bond principal rating is relatively poor; when the market and economy downturn, the bond principal rating is relatively high. In other words, the ratings of short-term financing bills show a counter-cyclical phenomenon. We propose the liquidity hypothesis for this phenomenon that during the period of economic prosperity, market liquidity and capital is relatively abundant; therefore even the companies with poor ratings have access to raise funds. When the market downturns and liquidity is poor, there are not enough funds in the market, thus the companies with poor ratings may fall to finance due to the lack of funds. Therefore, the liquidity of the market causes the bond rating to show a counter-cyclical phenomenon. Empirical research supports this hypothesis.
\end{abstract}

Keywords: Liquidity Expectation; Financing Ability; Credit Rating; Counter-Cyclical Phenomenon

\section{Introduction}

Since the subprime mortgage crisis, especially after 2011, many countries' sovereign rating and lots of corporations' credit rating have been continuously downgraded that makes the global economy keep falling. Therefore, the credit crisis has becoming important bottleneck and constraint for the global economic recovery. While during and after the crisis, the three largest credit rating agencies (e.g. Moody, S \& P and Fitch) have been heavily criticized, since the crisis has exposed many flaws of the credit rating agencies and the rating system. A serious problem is that the imperfection of the rating model greatly reduces the accuracy of credit rating. Therefore, to improve the rating model and make the credit rating accurately to reflect the default risk has been hotly discussed after the crisis.

As the development of China's securities market, corporate bonds have become an important investment for investors. And the important role of bond ratings in economic activities is increasingly exposed. Concerning the political/regulatory environment and credit rating in China, although crisis like the US subprime mortgage crisis has never happened, how the credit rating is assessed for domestic enterprises is seldom to be investigated. Besides the basic financial information as well as other "soft" information, how the macroeconomic policies impact the rating is also never discussed in China. Actually those questions are very important for global investors.

Some researchers find that the credit rating shows a pro-cyclical phenomenon in developed countries (see e.g. [1-3]), however a domestic report ${ }^{1}$ shows that the credit rating for bond in China is more likely to be upgraded during the economic downturns (see [4]), which seem to be an obvious counter-cyclical phenomenon. Therefore, how does the macro economy affect the bond rating in China? And what's the reason for the counter-cyclical phenomenon of bond rating? This paper attempts to discuss the credit rating and pro-cyclical or counter-cyclical phenomenon in China. We find that when the market and the economy upsurge, the bond principal rating is relatively poor; when the market and economy downturn, the bond principal rating is relatively high. In other words, the ratings of short-term financing bills show a counter-cyclical phenomenon. We propose the liquidity hypothesis for this phenomenon that during the period of economic prosperity, market liquidity and capital is relatively abundant;

\footnotetext{
${ }^{1}$ According to a document obtained by the "First Financial Daily" from the China Government Securities Depository Trust \& Clearing Corporation, during 2008 to 2010, follow-up ratings of bond issuers, a total of 388 ratings upgraded, only 13 downgraded. Especially in 2010, a total of 179 ratings upgrade, only 3 ratings downgraded. First Financial Daily, September 19, 2011.
} 
therefore even the companies with poor ratings have access to raise funds. When the market downturns, liquidity is poor, and there are not enough funds on the market, the companies with poor main rating may fall to finance due to the lack of access to funds. Therefore, the liquidity of the market causes the bond rating to show the countercyclical phenomenon. Our empirical research supports this hypothesis.

Section 2 reviews the previous rating literatures, and section 3 shows our hypothesis. Sections 4 and 5 are research design and empirical tests. Conclusions are shown in Section 6.

\section{Literature Review}

Bond rating first appeared in the United States at the beginning of the 20th century. John Moody uses symbols to show the pros and cons of grade of the various grades of railway bonds in 1909, this is the first bond rating in the United States. “The Great Depression” in 1930s proves that the credit rating basically reflects the repayment of the bond, which increases the trust of investors in bond rating. Therefore, the bond rating is crucial for investors.

The bond's credit risk is generally considered to be the bond issuer's risk of bankruptcy and the default risk of the bond. In order to reflect those risks, credit rating model and method are important. Rating methods include: 1) The credit rating method; 2) The traditional credit rating method; 3) The credit scoring model method and 4) The credit risk model method. There are numbers of theoretical and empirical researches on credit rating models (see [5-10]). In rating model, the critical rating factors taken into account by rating agencies are primarily on two aspect: 1) On business, focusing on business size, diversity and regional distribution, the quality of the products or services, marketing capability and marketing networks; and 2) On financial analysis, focusing on the quality of financial information, the scale and quality of assets, capital structure and debt pressures, profitability, cash flow and other factors (see [11,12]).

The Standard \& Poor in its credit rating method mentioned that the rating method is not limited to the inspecttion of various financial indicators. Indeed, Butler and Fauver [13] study the sovereign credit ratings from the perspective of the legal and institutional environment. They find that the country's legal and institutional environment has conspicuous positive effect on the sovereign credit rating. In addition, the macroeconomic factors largely determine the microeconomic performance, so macroeconomic factors, especially the economic cycle, play a pivotal role on bond rating. Carling et al. [14] shows that a variety of variables of the macroeconomic environment have important explanatory power on corporate default risk. If the state of the economy is divided into the peak, normal and underestimate situation, it will be found that the probabil- ity and default is particularly sensitive to economic cycles (see [2]). Therefore, studying the credit rating at different time points of the economic cycle can demonstrate the impact of the economic cycle on bond rating. Treacy and Carey [1] also points out that the rating changes will be more significant in a recession or expansion, which means there are more downgrades during the recession and more ratings increased during the economic expansion.

Researches in China regarding credit rating are mainly on the rating methodology while research for factors affecting bond rating, both theoretical and empirical, is far lagging behind. By comparing the bond rating system of the United States, Germany and Japan, Liang [15] finds that the presence or absence of one country's rating system and its specific model is closely related to bank-firm relationship. He and Fang [16] propose that China should promote the healthy development of the bond rating industry by two ways, creating an external environment conducive to the healthy development of the rating industry and strengthening the building of the rating agencies. Chen and Guo [17], He and Jin [18] study the rating of corporate bonds primarily from the micro-factors. As to macroeconomic factors, especially about the economic cycle, monetary policy and institutional factors, there is less theoretical and empirical research. In China, the capital market's performance is largely depending on the policy, and the main business and the market is highly subject to the impact of the macroeconomic environment. For this reason, it is quite practical important to explore China's bond rating from a macro perspective.

\section{Hypothesis}

The rating agencies typically assess the rate of the enterprise on the business, financial aspects, as well as some other "soft factors". Therefore, the scale of business, diversity and regional distribution, the quality of the products or services, the marketing capability and marketing networks, the quality of financial information, the asset size and quality, the capital structure and debt pressures, the profitability and the cash flow are the most basic rating factors (see [11,12]). In fact, a corporation's credit rate is the estimation of its risk of default and bankruptcy. In other words, the credit ratings of companies that do not default and bankruptcy will be relatively higher. And the ways to avoid such problems is timely accessing to funds for reimbursement. This means that the enterprise has sufficient financing ability to pay the maturing debt timely, so the enterprise would not default. Even if due to operational problems, the enterprise is not profitable, as long as it can still get money, there would be no bankruptcy problem. Therefore, the key of corporate rating is whether it has a strong financing ability, if companies has a strong financing ability can reduce the possibility of default and bankruptcy. 
A large part of Chinese enterprises are state-owned enterprises, operational problems often undertaken by the government, so bankruptcy problems are rare. Of course, there may be the event of default. That is the company unable to pay maturing debts, but the government as a patron can solve the problem through debt forgiveness, debt-equity swap and other means. Of course, not all state-owned enterprises are able to be such a government's "pet”, because of their importance, there are some differences on the financing ability. China's private enterprises that have a certain political relations also can get strong support from the government on financing (see $[19,20]$ ). Of course, not all private enterprises have such a "political relations". In other words, there are big differences among the financeing ability of domestic enterprises. The differences of financing ability result in the diversity of maturing debt repayment, business failure and bankruptcy, which leading to the main rating difference. Therefore, we propose that:

Hypothesis 1: Financing capability is positively correlated with bond rating.

The economic cycles play a pivotal role in the bond rating, and the various variables of macro environment have important explanatory power on the corporate default risk (see [14]). The reason is that economic environmental impact the probability of default of the bond, of default is particularly sensitive to economic cycles (see [2]). There are more rating downgrades during the economic recession, whereas in the economic expansion there are more ratings increased (see [1]).

In fact, the impact of the economic cycle on the bond rating directly relate to the amount of funding available by the enterprise. During the economic downturn, the market relatively lacks of liquidity, so it is difficult for enterprises to obtain external financing, even if it wanted to issue bonds. The rating agencies will be relatively more cautious, and they tend to give poor evaluation on the corporations, so the rating of the enterprise will be adjusted accordingly. During the period of economic prosperity, market liquidity is better, and there are more enterprises entering the market for financing. The rating agencies are relatively more optimistic, so they will give companies higher ratings to the enterprise. It is because of the liquidity situation, the rating shows pro-cyclical utility with the economic cycle.

Therefore, the bond rating or the corporate rating is based on the expectation of the market liquidity. In other words, market liquidity will affect the rating of the enterprise. When the market is expected to be lacks of liquidity to a certain extent, and when the monetary policy tightening, are difficult to obtain funding, the anticipated development of the companies will be impacted by the tighter monetary policy. At the same time, the enterprises' future profitability will decline to a certain extent, so their ratings are relatively poor. Therefore, we assume that:
Hypothesis 2: The declining of Liquidity expectation is negatively related with bond rating.

When the market is expected to be lacks of liquidity to a certain extent, and the monetary policy tightening, it is difficult for the companies to obtain funds even if they have a strong financing ability, and the anticipated development of the companies will be influenced by the tighter monetary policy, and the future profitability will decline. Therefore, the declining in market liquidity will have a negative impact on the bond ratings, and this declining will reduce the positive impact of strong financing ability on the corporate bond rating. Therefore, we assume that:

Hypothesis 3: The declining of liquidity expectation will reduce the positive impact of the financing ability on bond rating.

\section{Research Design}

\subsection{Model and Variables}

The ratings that the agencies give to the enterprises are divided into different levels, so we use the Ordered Logit model for the empirical analysis, and the model is set as follows:

$$
\begin{aligned}
\text { Credit }= & \alpha_{0}+\alpha_{1} \text { List }+\alpha_{2} \text { ROE }+\alpha_{3} C P I+\alpha_{4} \text { CPI } \times \text { List } \\
& +\alpha_{5} C P I \times R O E+\alpha_{6} \text { GDPgrow }+\alpha_{7} \text { Inter cov er } \\
& +\alpha_{8} \text { Lev }+\alpha_{9} \text { Size }+\alpha_{10} \text { Age }+\alpha_{11} \text { Guarantee } \\
& +\alpha_{12} \text { IndSup }+\varepsilon
\end{aligned}
$$

Credit stands for the credit rating, which is the rating that the professional credit rating agencies give to the issuers when their bonds are issued. The credit rating includes AAA, AAA-, AA+, AA, AA-, A+, A, A- and $\mathrm{BBB}$ levels. In the regression of this paper, AAA and AAA - are classified as the first level, and assigned a value of 3. AA+, AA and AA- are regarded as the second level, assigned a value of $2 . \mathrm{A}+, \mathrm{A}, \mathrm{A}-$ and $\mathrm{BBB}+$ are the third level $^{2}$, assigned a value of 1 . In robust test, the ratings are divided into 9 degrees, AAA is the first degree, a value of 8; AAA- is the second degree, the assignment is 7; descending order of $\mathrm{BBB}+$ for the ninth degree, the assignment is zero.

This paper uses List and ROE to measure the financing ability. The listed companies can absorb funds from the stock market, so compared to the non-listed companies their financing channels are relatively broader. What's more is that a listed company's "shell” is valuable, thus the listed companies have better access to gain debt capital. Therefore, in terms of the financing channels and financing strength the listed companies are more competitive than the non-listed companies. While the higher profitability of a company, the stronger ability it has to gain benefit

${ }^{2}$ There are just two samples' rating are $\mathrm{BBB}+$, so they are classified in the third level. 
for shareholders, and it can protect the interests of creditors' better, which can improve its ability to absorb new funds. The higher profitability of the company, the easier for the company to be listed to obtain funds, and it is easier for it to issue or allot shares on the capital market, the more loans it can get from creditors. Therefore, the profitability reflects the financing ability to a certain extent, the higher profitability of the corporations, the stronger financing ability of them. Based on hypothesis 1 , we expect $\alpha_{1}>0$, and $\alpha_{2}>0$.

Market liquidity expectation is proxy by CPI, and we use the consumer price index (CPI) of the bond issuance's month ${ }^{3}$. Higher CPI stands for severer inflation, which means that the central bank tends to adjust the market liquidity by means of monetary policy or market operations to reduce the external currency flows. Therefore higher CPI means the lower market liquidity expectation $^{4}$. Although the growth rates of narrow money (M1) and broad money (M2) also represent the market liquidity, the higher CPI is more likely to mean a tightening of monetary policy in the future, while higher growth rate of M1 or M2 does not more likely mean tighten monetary policy. Thus the CPI reveals liquidity expectation. Based on hypothesis 2, we expect $\alpha_{3}<0$.

CPI $\times$ List and CPI $\times$ ROE are the cross-terms of the market liquidity expectation and the corporations' financeing ability. Based on hypothesis 3, we predict that $\alpha_{4}<0$ and $\alpha_{5}<0$.

GDPgrow is the measurable variable of output growth ("economic cycle"), by deducting the real GDP growth rate by the expected GDP growth. The real GDP growth rate can be found in the China Statistical Yearbook, and the World Bank's growth expectations of the economy about the countries around the world will be adjusted according to actual situation and the macroeconomic environment, which have a high correlation with the macroeconomic environment, so we have chosen the world Bank's economy forecast data on China as the source of the expected GDP growth. This variable reveals the gap between the real economic growth and the economic growth potential, and it reflects the relative strength of the current macroeconomic situation, so we use it as a measurable indicator of the economic cycle.

Intercover is the interest coverage ratio, which equals (total profit + financial expenses)/finance expenses. Lev is the leverage ratio, equals to total liabilities/total assets.

\footnotetext{
${ }^{3}$ Rating often is given a few months before the bond issuance, so it is somewhat lag to use the CPI of issuance month, which is equivalent to expect the CPI after the credit rating.

${ }^{4}$ This paper has verified the effective of the CPI to represent the liquidity expectation. The growth rate of M1 and M2 represent the market liquidity, while the correlation coefficients of the CPI with the growth rate of M1 and M2 are -0.2439 and -0.2284 , both significant at 0.01 level. That is CPI is significantly negative correlate with the liquidity indicators. So CPI on behalf of liquidity expectation is reasonable.
}

Size stands for the firm size, and we use the natural logarithm of the total assets. Age represents the life cycle of the enterprises, which is equivalent to the years of establishment up to the month of the security issuance. Guarantee is a dummy variable, 1 indicates that the issued securities were guaranteed and 0 otherwise. IndSup is a dummy variable for the industry, 1 indicates the industries which are supported by the Chinese industry policy and 0 otherwise.

The data used in the calculation of the above variables are the financial data disclosed in the financial statements of the previous year that the securities are issued.

\subsection{Data Sources and Sample}

We collect all the documents of short-term financing bills issued during 2005 to 2010 from the China Bond Information Network

(http://www.chinabond. com.cn/d2s/index.html).

The documents include bonds issued document, the prospectus, the credit rating reports, the financial statements. And we collect the issuers' credit rating, the ownership structure, the audit institutions, the financial data disclosed in the bond issuance files manually. Due to missing data for some samples' issuer credit rating and financial information, the final sample is 1550 issuance.

Meanwhile, we collect China's GDP growth during 2005 and 2010 as well as CPI data from the China Statistical Yearbook, and collect the World Bank's latest forecast data about China's annual GDP growth rate from 2005 to 2010 on the website of the World Bank.

\section{Empirical Analysis}

\subsection{Descriptive Statistics}

Table 1 shows the descriptive statistics of regression variables. The average of issuer credit rating is 2 which means the majority of the issuer ratings is above A. $32.7 \%$ of the total samples are listed firms which means the most

Table 1. Descriptive statistics.

\begin{tabular}{ccccccc}
\hline Variable & $\mathrm{N}$ & Mean & Std. & Min & Median & Max \\
\hline Credit & 1550 & 2.060 & 0.590 & 1 & 2 & 3 \\
List & 1550 & 0.327 & 0.469 & 0 & 0 & 1 \\
ROE & 1550 & 0.088 & 0.089 & -0.655 & 0.076 & 1.017 \\
CPI & 1550 & 0.030 & 0.026 & -0.018 & 0.028 & 0.087 \\
GDPgrow & 1550 & 0.010 & 0.011 & -0.009 & 0.008 & 0.026 \\
Intercover & 1550 & 10.758 & 20.550 & 0 & 4.2795 & 100 \\
Lev & 1550 & 0.567 & 0.178 & 0.016 & 0.599 & 0.977 \\
Size & 1550 & 14.496 & 1.382 & 9.867 & 14.331 & 19.319 \\
Age & 1550 & 12.988 & 7.380 & 0.356 & 11.902 & 92.060 \\
Guarantee & 1550 & 0.016 & 0.126 & 0 & 0 & 1 \\
IndSup & 1550 & 0.392 & 0.488 & 0 & 0 & 1 \\
\hline
\end{tabular}


issuers of short-term financing bonds are non-listed companies. The average return on equity rate is $8.8 \%$ and the median is $7.6 \%$. For the macroeconomic aspect, the average CPI increasing is $3 \%$, while the maximum increasing is $8.7 \%$, and the lowest increasing is $-1.8 \%$. The average GDP growth gap is $1 \%$, and it changes from the highest $2.6 \%$ to the lowest $-0.9 \%$. The overall economic development shows a large volatility from 2005 to 2010 . Other financial data also show great differences.

Table 2 shows credit ratings for issuing entity of the sample short-term financing bills ${ }^{5}$. Since the short-term financing bills market was started in 2005, more and more companies can get funds from this market, especially in the 2010 for there is a blowout in the number of issuing firms. For these companies that get short-term funds, there are significant differences among their credit ratings. There are 320 samples that get the highest level of rating AAA, which accounts for $20 \%$ of the total samples. About $65 \%$ of the issuers rated as AA, and $15 \%$ of the samples' ratings are A. Although these companies are able to issue short-term financing bills in the market, their risk is still quite different.

Figure 1 shows the evolution of the credit ratings of these samples. The number of firms that are rated as A was increasing year by year from 2005 to 2007, and the proportion rose to about $30 \%$, while the samples' proportion of the AA and AAA level are relative declining. The situation changed from 2008, the proportion of the samples that rated the A level decreased significantly, while the proportion of the other two categories of samples increased significantly.

Actually from 2005 to 2007, the global economy is in boom. However, the subprime mortgage crisis that broke out in the end of 2007 made the global economy fell into a recession. Therefore, the economic growth or the market condition shows an opposite trend with the credit rating change during 2005 and 2010 in China, which means the issuer credit ratings are relatively poor when the market and the economy are prosperous; the issuer credit

Table 2. Short-term financing bills issuer credit rating.

\begin{tabular}{cccccccc}
\hline & 2005 & 2006 & 2007 & 2008 & 2009 & 2010 & Total \\
\cline { 2 - 8 } A & 7 & 57 & 79 & 41 & 13 & 29 & 226 \\
AA & 46 & 146 & 145 & 174 & 188 & 305 & 1004 \\
AAA & 26 & 35 & 39 & 52 & 61 & 107 & 320 \\
Total & 79 & 238 & 263 & 267 & 262 & 441 & 1550 \\
\hline
\end{tabular}

Note: AAA includes AAA and AAA-, AA includes AA+, AA and AA-, A includes $\mathrm{A}+, \mathrm{A}$ and $\mathrm{A}_{-}{ }^{6}$.

${ }^{5}$ In China, all the credit ratings for short-term financing bills are A-1, showing no differences. While the credit rating for issuing entity has great differences, from $\mathrm{A}-$ to AAA.

${ }^{6}$ There are two samples' credit ratings are $\mathrm{BBB}+$. Due to small sample size, this article classifies them to A.

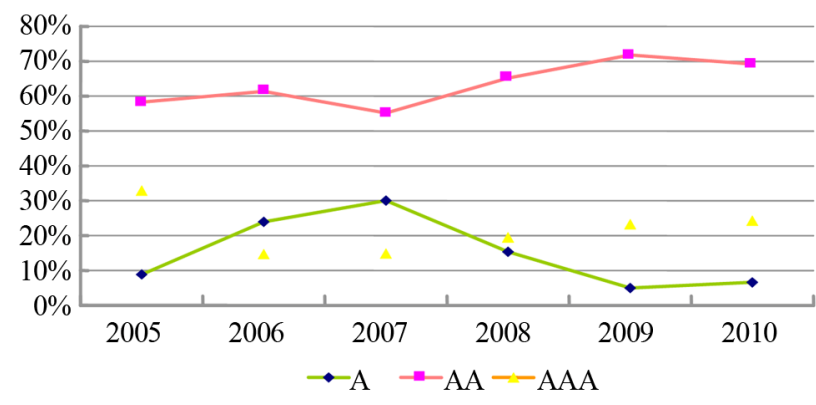

Figure 1. The credit rating for short-term financing bills.

ratings are relatively better when the market and the economy downturn. In other words, the credit rating of shortterm financing bills shows a counter-cyclical phenomenon in China. The possible reason is that: 1) Lots of companies entered the market to get funds and the market liquidity was strong when the economy was in boom, and the capital is relatively abundant, so even the companies with poor credit ratings can make access to funds. When the market is downturn, the liquidity is poor and the funds is not enough on the market, the companies with poor ratings may fail to finance due to the lack of access to funds, so this reduce the proportion of the low ratings. Therefore, it is the market liquidity that causes the credit rating shows the counter-cyclical phenomenon; 2) The rating agencies manipulated the ratings. The market is lack of liquidity when the economy is relatively poor, the corporations with poor ratings can't make access to finance since the fund is not enough on the market. So in order to gain earnings the rating agencies may artificially loose the rating criteria and raise the issuer credit ratings. Therefore, the final result is that the proportion of the companies with poor ratings declined and there were more corporations that have good ratings. Whatever is the reason, the fundamental problem is that the market is lack of liquidity and funds.

Table 3 shows the statistical data of listed and non-listed samples. Non-listed sample is the majority, it accounts for about $67 \%$, and the listed samples accounted for approximately $33 \%$ of the total samples.

Figure 2 shows the proportion of the listed samples and the non-listed samples. From 2005 to 2008, the proportion of the non-listed companies is rising, and more and more listed companies came to raise funds in the shortterm financing bills market after 2008. The stock market fell sharply in 2008, even the listed companies were difficult to raise funds by issuing stocks, so many companies choose the bond market to finance, thereby squeezed the financing ability of the non-listed companies. Compared to the non-listed companies, the listed companies have more channels of financing.

Table 4 compares the financing ability between listed samples and non-listed samples. The leverage ratio reflects 
Table 3. The listing situation of the short-term financing bills issuers.

\begin{tabular}{cccccccc}
\hline & 2005 & 2006 & 2007 & 2008 & 2009 & 2010 & All \\
\cline { 2 - 8 } Non-listed Samples & 51 & 143 & 186 & 200 & 177 & 286 & 1043 \\
Listed Samples & 28 & 95 & 77 & 67 & 85 & 155 & 507 \\
All & 79 & 238 & 263 & 267 & 262 & 441 & 1550 \\
\hline
\end{tabular}

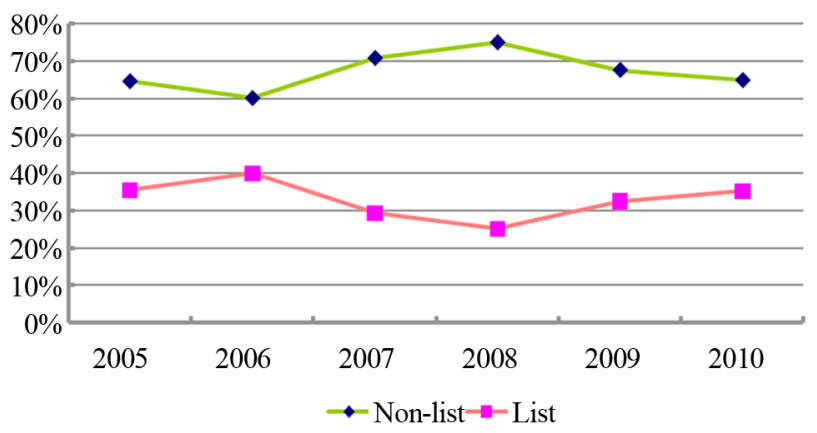

Figure 2. Proportions of listed and non-listed samples each year.

Table 4. The listed and non-listed samples' financing ability comparison.

\begin{tabular}{ccccc}
\hline & \multicolumn{2}{c}{ Lev } & \multicolumn{2}{c}{ ROE } \\
\cline { 2 - 5 } & Mean & Median & Mean & Median \\
\cline { 2 - 5 } Non-listed Sample & 0.583 & 0.623 & 0.085 & 0.069 \\
Listed Sample & 0.535 & 0.548 & 0.096 & 0.089 \\
Difference & 0.048 & 0.075 & -0.011 & -0.019 \\
t/Z Value & $5.070^{* * *}$ & $6.534^{* * *}$ & $-2.312^{* *}$ & $-5.742^{* * *}$ \\
\hline
\end{tabular}

Note: Lev is the latest asset-liability ratio of the short-term financing bills issuers, and it equals to total liabilities/total assets. ROE is the latest return on equity of the short-term financing bills issuers, and it equals to net profit/ equity.

the companies' future financing space of debt, and the profitability reflects the basic financing ability. The average leverage ratio for non-listed samples is 0.583 , and the median is 0.623 , both are significantly higher than listed samples. In other words, the listed samples' debt financing space is relatively higher. For the profitability indicator ROE, non-listed samples' average is 0.085 , and the median is 0.069 , both are significantly lower than listed samples, which means the profitability and financing ability of listed samples are stronger than non-listed companies. In short, according to the comparison of leverage and profitability in Table 4, the financing ability of listed companies is stronger than non-listed companies. Integrated with the Tables 2 and 3, it shows that the financing ability (including funding sources and financing strength) of listed companies is stronger than non-listed companies.

\subsection{Regression Analysis}

Table 5 shows the regression results ${ }^{7}$. Coefficient of eco- nomic cycle variable (GDPgrow) is significantly negative in all regressions, which is consistent with the trend in Figure 1 and means the issuer credit ratings of the shortterm financing bills show a counter-cyclical phenomenon. When the economic growth is poor, the issuer credit ratings are quite good; on the contrary, when the economic growth is good, the issuer credit ratings are poor. The coefficient of the interest coverage ratio (Intercover) is significantly positive, and it indicates that the better solvency of the bond issuance enterprise, the higher of its credit rating. The enterprise with higher debt ratio, the potential of its financing ability is relatively lower, so its credit rating is relatively low. The risk of the larger companies is generally lower, so their credit ratings are higher. The life cycle of the bond issuers does not have significant impact on the credit rating (Age's coefficient is not significant). The credit ratings of guaranteed bonds' issuers are not high, and the coefficient of the Guarantee variable is significantly negative. The likely reason is that the companies with strong solvency usually do not need to guarantee their bond, and the bonds of inferior corporations will be asked to be guaranteed. In addition, enterprises in the industry of the national policy support (IndSup $=1$ ), will receive state support on operating and debt service in the future, so the risk is relatively low, and their issuer credit ratings are high.

We control those above factors to test the influence of the financing ability on the credit rating in Model 1 . The coefficient of listing variable (List) is significantly positive at the 0.01 level. It means the listed companies' credit ratings are higher than the non-listed companies, which illustrates whether listed will significantly affect the issuers' credit rating. Compared to non-listed companies, the listed companies have the qualifications and capabilities to raise funds on the capital markets; what's more, the specific listing "shell” of Chinese capital market makes the listed companies having the ability to attract other funds. The coefficient of profitability (ROE) is also significantly positive at the 0.05 level. That is, the stronger of the corporations' profitability, the higher of their credit rating. The profitability represent the potential of financing, and the enterprises with strong financing potential can solve the existing financial problems by financing through other means when they have difficulties to repay maturing debts, so their credit ratings are relatively high. The listed variable (List) and the profitability variable (ROE) that are on behalf of the corporations' financing capabilities are significantly positive correlated with the issuer rating, so the Hypothesis 1 is supported.

We then add the liquidity expectation variable in Model 2. The higher of the current CPI, the more likely that the central bank will tighten the monetary policy in the coming

${ }^{7}$ The largest correlation coefficient between the explanatory variables is 0.275 , that there is no serious co-linearity problem. 
Table 5. The financing capabilities, market liquidity and the credit rating.

\begin{tabular}{|c|c|c|c|c|c|c|c|c|}
\hline Variable & Sign Expectation & Model 1 & Model 2 & Model 3 & Model 4 & Model 5 & Model 6 & Model 7 \\
\hline \multirow[t]{2}{*}{ List } & + & $0.351^{* * *}$ & $0.297^{* *}$ & $0.636^{* * *}$ & $0.299^{* *}$ & $0.632^{* * *}$ & $0.628^{* * *}$ & $0.444^{*}$ \\
\hline & & $(2.67)$ & $(2.23)$ & (3.12) & $(2.24)$ & (3.11) & $(3.07)$ & $(1.74)$ \\
\hline \multirow[t]{2}{*}{ ROE } & + & $1.634^{* *}$ & $1.846^{* * * *}$ & $1.839^{* * * *}$ & $3.523^{* * *}$ & $3.540^{* * *}$ & $3.505^{* * * *}$ & $3.719^{* * * *}$ \\
\hline & & $(2.36)$ & (2.66) & $(2.64)$ & (3.61) & (3.59) & (3.55) & (3.19) \\
\hline \multirow[t]{2}{*}{ CPI } & - & & $-17.911^{* * * *}$ & $-14.474^{* * *}$ & $-12.843^{* * *}$ & $-9.363^{* * * *}$ & $-8.883^{* *}$ & $-10.966^{* * *}$ \\
\hline & & & $(-7.28)$ & $(-4.98)$ & $(-3.96)$ & $(-2.60)$ & $(-2.44)$ & $(-2.41)$ \\
\hline \multirow[t]{2}{*}{$\mathrm{CPI} \times$ List } & - & & & $-11.066^{* *}$ & & $-10.946^{* *}$ & $-11.311^{* * *}$ & -8.091 \\
\hline & & & & $(-2.20)$ & & $(-2.19)$ & $(-2.26)$ & $(-1.32)$ \\
\hline \multirow[t]{2}{*}{$\mathrm{CPI} \times \mathrm{ROE}$} & - & & & & $-56.742^{* *}$ & $-57.014^{* *}$ & $-57.944^{* * *}$ & $-74.297^{* * * *}$ \\
\hline & & & & & $(-2.39)$ & $(-2.40)$ & $(-2.42)$ & $(-2.64)$ \\
\hline \multirow[t]{2}{*}{ GDPgrow } & $?$ & $-18.903^{* * *}$ & $-25.142^{* * *}$ & $-25.293^{* * *}$ & $-25.288^{* * *}$ & $-25.730^{* * * *}$ & $-25.363^{* * *}$ & $-22.073^{* * *}$ \\
\hline & & $(-3.43)$ & $(-4.44)$ & $(-4.46)$ & $(-4.46)$ & $(-4.54)$ & $(-4.47)$ & $(-3.07)$ \\
\hline \multirow[t]{2}{*}{ Intercover } & + & $0.015^{* * * *}$ & $0.015^{* * * *}$ & $0.015^{* * *}$ & $0.015^{* * *}$ & $0.015^{* * * *}$ & $0.015^{* * * *}$ & $0.014^{* * * *}$ \\
\hline & & $(4.70)$ & $(4.70)$ & $(4.72)$ & (4.73) & $(4.74)$ & (4.73) & (3.77) \\
\hline \multirow[t]{2}{*}{ Lev } & - & $-0.940^{* *}$ & $-1.557^{* * *}$ & $-1.484^{* * *}$ & $-1.529^{* * *}$ & $-1.450^{* * * *}$ & $-1.430^{* * * *}$ & $-1.438^{* * * *}$ \\
\hline & & $(-2.54)$ & $(-4.08)$ & $(-3.87)$ & $(-4.00)$ & $(-3.78)$ & $(-3.71)$ & $(-2.88)$ \\
\hline \multirow[t]{2}{*}{ Size } & + & $1.359^{* * * *}$ & $1.415^{* * *}$ & $1.418^{* * * *}$ & $1.420^{* * * *}$ & $1.422^{* * * *}$ & $1.411^{* * * *}$ & $1.441^{* * * *}$ \\
\hline & & (20.11) & (20.34) & (20.32) & (20.34) & (20.33) & (20.21) & (15.21) \\
\hline \multirow[t]{2}{*}{ Age } & $?$ & 0.008 & 0.007 & 0.010 & 0.009 & 0.007 & 0.006 & 0.002 \\
\hline & & (1.03) & $(0.82)$ & (1.11) & (1.04) & $(0.83)$ & $(0.78)$ & $(0.22)$ \\
\hline \multirow[t]{2}{*}{ Guarantee } & + & $-1.216^{* * *}$ & $-1.332^{* * *}$ & $-1.334^{* * *}$ & $-1.364^{* * *}$ & $-1.363^{* * * *}$ & & $-1.824^{* * * *}$ \\
\hline & & $(-2.74)$ & $(-2.89)$ & $(-2.91)$ & $(-2.97)$ & $(-2.98)$ & & $(-3.42)$ \\
\hline \multirow[t]{2}{*}{ IndSup } & + & $0.417^{* * *}$ & $0.367^{* * *}$ & $0.380^{* * * *}$ & $0.383^{* * *}$ & $0.393^{* * * *}$ & $0.367^{* * * *}$ & \\
\hline & & $(3.24)$ & $(2.82)$ & $(2.92)$ & $(2.94)$ & $(3.01)$ & $(2.80)$ & \\
\hline $\mathrm{N}$ & & 1550 & 1550 & 1550 & 1550 & 1550 & 1525 & 941 \\
\hline LR chi2 & & 794.55 & 849.59 & 855.00 & 855.67 & 860.00 & 830.50 & 439.94 \\
\hline R-sq & & 0.2887 & 0.3087 & 0.3107 & 0.3109 & 0.3125 & 0.3072 & 0.2741 \\
\hline
\end{tabular}

Note: The figures in the brackets are white-t statistic, and the paper has considered the problem of heteroscedasticity; ${ }^{* * *}{ }^{* *}{ }^{*}{ }^{*}$ denote signif icant at the $0.01,0.05$ and 0.10 level.

month or months, and the liquidity of the capital market will be lowered, which may raise the cost of debt financing, and simultaneously raise the corporations' cost of funds, and finally have a negative impact on the business. In other words, the worse of the liquidity expectation (the higher of the CPI), the higher of the cost of funds, which may generate a negative impact on the corporations' performance and solvency, and it lowers the credit rating. The Hypothesis 2 is supported. The coefficients of the listed variable (List) and the profitability (ROE) are still significantly positive. That is the stronger of the financing ability, the higher of the credit rating, so the Hypothesis 1 is still supported.

In Model 3 and Model 4 we respectively analyses the influence of the liquidity expectation to the impact of the financing ability on the credit rating by using two financing ability variables. The list variable (CPI $\times$ List) is taken into account in Model 3, and the profitability (CPI $\times$ ROE) is considered in Model 4, and then this paper conducts a comprehensive analysis of this two aspects (CPI $\times$ List, CPI $\times$ ROE) in Model 5. The coefficients of the list variable (List) and the profitability (ROE) are still significantly positive, and the coefficient of the liquidity expectation
(CPI) is still significantly negative, all of which is consistent with the previous results.

The coefficients of CPI $\times$ List and CPI $\times$ ROE are significantly negative at the 0.05 level. That means the liquidity expectation not only has a negative impact on the bond rating directly, but also reduces the positive contribution of the financing ability on the credit rating. Despite whether the issuers are listed and have strong profitability or not, the liquidity expectation will lower the credit rating of the bond issuers.

Part of the sample companies issued short-term financing bills with guarantee, which may show a different trend; therefore we exclude the samples that are guaranteed in Model 6, while the result is entirely consistent with the previous. Financing ability is positive with the credit rating, and the liquidity expectation has a negative impact on the credit rating, the poor liquidity expectation will lower the credit rating directly and simultaneously let down the positive impact of the financing ability on the credit rating.

Some samples' issuers belong to the industry that has the great support from the government and the effect of the policy may be very small on them, even if the monetary is tightened. So the paper excludes the samples belong to 
the support industry in Model 7. Similarly, the result is still consistent with previous, and the Hypothesis 1 and the Hypothesis 2 are still supported.

In summary, the results in Table 5 show that the financing ability can significantly improve the enterprise's credit rating, but this ability will be influenced by the monetary policy or the liquidity expectation. The liquidity expectation has a significant negative impact on the issuer credit rating.

Passive rating may be helpful for the rating objects to establish some kind of "relationship" with the rating agencies, and the rating agencies tend to rely on the "soft" information obtained through internal channels rather than the "hard" information got from the open market when the rating agencies have "relationship" with the rating objects. Chang et al. [21] found that the banks took "soft information" into account when they loaned to the enterprises, such as whether state-owned and the equity ratio of the controlling shareholder. Therefore, the robustness test showed in Table 6, and Model 8 controls the relevant characteristics of the ownership structure. State represents the nature of the ultimate controller, 1 stands for stateowned, and 0 otherwise. $\mathrm{V}$ is control right (Voting right) of the ultimate controller, Deviation is the difference between the control right and the cash flow right of the ultimate controller, the calculation method is same as the research of Fan and Wong $[22]^{8}$. The results show that the nature of the enterprises (State or not) has significant effect on the credit rating. And the state-owned enterprises' credit ratings are significantly higher than the non-stateowned enterprises. The reason of this phenomenon is the state-owned enterprises have the final backing-Government. The Government will lend a "helping hand" to solve the problems when the corporations encounter problems on business. The coefficient of the ultimate controllers' equity ratio (V) is significantly positive. That is, the higher of the corporations' equity ratio, the higher of the credit rating. The possible reason is that the major shareholders of the corporations with high control right have lower motivation to empty the enterprises (see [23]).

The coefficient of the control right and the cash flow right discrepancy (Deviation) is negative, but it is not significant. Financing ability (List and ROE) is positive with the credit rating, and the liquidity expectation has a negative impact on the credit rating.

The poor liquidity expectation will lower the credit rating directly and simultaneously let down the positive impact of the financing ability on the credit rating (the coefficients of the CPI $\times$ LIST and CPI $\times$ ROE are significant at the 0.05 level). Our three hypotheses are supported.

The previous study found that the accounting information played an important role on the corporations' invest-

\footnotetext{
${ }^{8}$ The status of the shareholders is disclosed in the prospectus.

${ }^{9}$ The audit firm rankings refer to the 2010 national firm rankings.
}

ment and financing (see [24]), and this indicated that the accounting information may also play a key role on the credit rating. Therefore, this paper controls the influence of the accounting information quality on the credit rating in Model 9. We choose the bond issuers' audit institutions as dummy variables of the quality of the accounting information. Big4 is a dummy variable, 1 means that the auditing firms are the four biggest international audit firms and 0 otherwise. Top10 is the dummy variable of the Chinese audit firms' top ten ${ }^{9}, 1$ means that the audit firms are the biggest ten of Chinese audit agencies, and 0 otherwise. It is generally accepted that the customers' accounting information quality of the Big Four audit is better than the top ten audit agencies, and both are higher than the companies that audited by Chinese non-top ten audit firms. The results show that the quality of the accounting information significantly affects the credit rating. The higher is the information's quality, the better of the credit rating. The financing ability (List and ROE) is positive with the credit rating, whereas the poor liquidity expectation will lower the credit rating directly (the coefficient of the CPI is significantly negative) and simultaneously let down the positive impact of the financing ability on the credit rating (the coefficients of the CPI $\times$ LIST and CPI $\times$ ROE are significant at the 0.05 level). The three hypothesis of this paper are supported.

Since the financial crisis, the reputation and credibility of the international rating agencies have been criticized, and other small rating agencies' credibility is even more doubtful. While the rating business of China's short-term financing bills market is basically monopolized by four Chinese rating agencies: the Emirates International Credit Rating Co., Ltd., the Integrity of the International Credit Rating Co., Ltd., Joint Credit Rating Co., Ltd. and Shanghai New Century Ratings Co., Ltd.

Except for the Emirates International, the other three rating agencies are more or less controlled by foreign capital, and this difference of the ownership property may lead to the distinction of the risk controlling. Cantor and Packer [25] find that the rating results made by the rating agencies are usually opposite with the viewpoint of the investors and the regulators, and the connotation of the rating made by different rating agencies at different times is quite different. Therefore, we further control the difference of rating agencies in Model 10. The result shows that the issuer credit ratings made by the Emirates International Credit Rating Co., Ltd. are significantly lower than the other three agencies. The possible explanations for that is the rating criteria of the Emirates International Credit Rating Co., Ltd. is more stringent than the other three, and another reason may be the quality of its customers is relatively poor. The coefficients of the financing ability (List and ROE), liquidity expectation (CPI) and the crossvariables (CPI $\times$ LIST and CPI $\times$ ROE) are consistent with 
Table 6. The robustness test.

\begin{tabular}{|c|c|c|c|c|c|c|}
\hline \multirow[b]{2}{*}{ Variable } & Model 8 & Model 9 & Model 10 & Model 11 & Model 12 & Model 13 \\
\hline & Ownership & Information quality & Audit agency & List & Non-listed & Detailed rating \\
\hline \multirow[t]{2}{*}{ List } & $1.110^{* * *}$ & $0.906^{* * *}$ & $0.876^{* * *}$ & & & $0.696^{* * *}$ \\
\hline & $(4.63)$ & (3.67) & $(3.53)$ & & & (3.56) \\
\hline \multirow[t]{2}{*}{ ROE } & $3.669^{* * *}$ & $3.810^{* * *}$ & $3.790^{* * * *}$ & $4.108^{* *}$ & $3.252^{* *}$ & $2.782^{* * *}$ \\
\hline & (3.73) & $(3.80)$ & $(3.77)$ & $(2.41)$ & $(2.45)$ & $(3.42)$ \\
\hline \multirow[t]{2}{*}{ CPI } & $-9.282^{* *}$ & $-8.307^{* *}$ & $-8.109^{* *}$ & $-21.208^{* * *}$ & $-7.716^{*}$ & $-9.973^{* * *}$ \\
\hline & $(-2.57)$ & $(-2.28)$ & $(-2.22)$ & $(-3.11)$ & $(-1.93)$ & $(-3.35)$ \\
\hline \multirow[t]{2}{*}{$\mathrm{CPI} \times$ List } & $-11.272^{* *}$ & $-9.941^{*}$ & $-10.061^{* *}$ & & & -4.415 \\
\hline & $(-2.23)$ & $(-1.94)$ & $(-1.97)$ & & & $(-1.09)$ \\
\hline \multirow[t]{2}{*}{$\mathrm{CPI} \times \mathrm{ROE}$} & $-57.557^{* *}$ & $-61.624^{* *}$ & $-62.212^{* * *}$ & -49.958 & $-61.170^{* *}$ & $-33.546^{*}$ \\
\hline & $(-2.42)$ & $(-2.57)$ & $(-2.58)$ & $(-0.96)$ & $(-2.06)$ & $(-1.65)$ \\
\hline \multirow[t]{2}{*}{ GDPgrow } & $-25.643^{* * *}$ & $-24.009^{* * *}$ & $-24.057^{* * *}$ & $-29.194^{* * *}$ & $-23.673^{* * *}$ & $-14.475^{* * *}$ \\
\hline & $(-4.51)$ & $(-4.16)$ & $(-4.16)$ & $(-2.68)$ & $(-3.38)$ & $(-3.09)$ \\
\hline \multirow[t]{2}{*}{ Intercover } & $0.015^{* * * *}$ & $0.012^{* * * *}$ & $0.011^{* * * *}$ & 0.001 & $0.016^{* * * *}$ & $0.012^{* * *}$ \\
\hline & $(4.72)$ & (3.59) & (3.52) & $(0.14)$ & (3.91) & (4.69) \\
\hline \multirow[t]{2}{*}{ Lev } & $-1.576^{* * *}$ & $-1.574^{* * *}$ & $-1.548^{* * *}$ & $-1.801^{* *}$ & $-1.183^{* *}$ & $-1.867^{* * *}$ \\
\hline & $(-4.07)$ & $(-4.01)$ & $(-3.94)$ & $(-2.34)$ & $(-2.50)$ & $(-5.73)$ \\
\hline \multirow[t]{2}{*}{ Size } & $1.366^{* * *}$ & $1.308^{* * *}$ & $1.298^{* * * *}$ & $1.417^{* * *}$ & $1.251^{* * *}$ & $1.339^{* * *}$ \\
\hline & (19.27) & (18.17) & $(17.92)$ & $(9.15)$ & $(14.91)$ & (22.67) \\
\hline \multirow[t]{2}{*}{ Age } & 0.007 & 0.005 & 0.005 & -0.030 & 0.009 & 0.007 \\
\hline & $(0.79)$ & $(0.59)$ & $(0.55)$ & $(-0.95)$ & $(1.01)$ & $(1.00)$ \\
\hline \multirow[t]{2}{*}{ Guarantee } & $-1.487^{* * *}$ & $-1.536^{* * * *}$ & $-1.559^{* * * *}$ & -0.467 & $-1.914^{* * * *}$ & $-0.893^{* *}$ \\
\hline & $(-3.22)$ & $(-3.27)$ & $(-3.31)$ & $(-0.45)$ & $(-3.47)$ & $(-2.49)$ \\
\hline \multirow[t]{2}{*}{ IndSup } & $0.342^{* * *}$ & $0.363^{* * *}$ & $0.373^{* * *}$ & 0.409 & $0.300^{*}$ & $0.325^{* * *}$ \\
\hline & $(2.60)$ & (2.73) & $(2.79)$ & (1.48) & $(1.90)$ & (3.09) \\
\hline \multirow[t]{2}{*}{ State } & $0.508^{* * *}$ & $0.484^{* * *}$ & $0.476^{* * *}$ & $0.438^{*}$ & $0.716^{* * *}$ & $0.465^{* * *}$ \\
\hline & (2.97) & $(2.81)$ & $(2.76)$ & $(1.67)$ & (2.89) & (3.39) \\
\hline \multirow[t]{2}{*}{$\mathrm{V}$} & $0.006^{*}$ & $0.008^{* *}$ & $0.007^{* *}$ & $0.022^{* * *}$ & 0.001 & $0.005^{* *}$ \\
\hline & (1.75) & (2.32) & $(2.30)$ & $(3.21)$ & $(0.33)$ & (2.06) \\
\hline \multirow[t]{2}{*}{ Deviation } & -0.013 & -0.013 & -0.013 & -0.023 & 0.005 & -0.010 \\
\hline & $(-1.21)$ & $(-1.25)$ & $(-1.27)$ & $(-1.64)$ & $(0.26)$ & $(-1.22)$ \\
\hline \multirow[t]{2}{*}{ Big4 } & & $1.143^{* * * *}$ & $1.113^{* * * *}$ & $1.059^{* * * *}$ & $1.706^{* * *}$ & $0.954^{* * *}$ \\
\hline & & (4.89) & $(4.75)$ & (3.11) & (3.91) & (4.96) \\
\hline \multirow[t]{2}{*}{ Top10 } & & $0.544^{* * *}$ & $0.557^{* * *}$ & $0.700^{* *}$ & $0.472^{* *}$ & $0.537^{* * *}$ \\
\hline & & (3.49) & $(3.54)$ & $(2.24)$ & $(2.50)$ & $(4.35)$ \\
\hline \multirow[t]{2}{*}{ SHNCR } & & & -0.070 & 0.326 & -0.496 & 0.270 \\
\hline & & & $(-0.31)$ & $(0.97)$ & $(-1.52)$ & (1.49) \\
\hline \multirow[t]{2}{*}{ EICR } & & & $-0.273^{*}$ & -0.081 & $-0.315^{*}$ & -0.154 \\
\hline & & & $(-1.72)$ & $(-0.27)$ & $(-1.65)$ & $(-1.23)$ \\
\hline \multirow[t]{2}{*}{ IICR } & & & -0.191 & $-0.668^{* *}$ & -0.001 & -0.052 \\
\hline & & & $(-1.22)$ & $(-2.25)$ & $(-0.00)$ & $(-0.42)$ \\
\hline $\mathrm{N}$ & 1550 & 1550 & 1550 & 507 & 1043 & 1550 \\
\hline LR chi2 & 879.32 & 910.87 & 914.27 & 350.53 & 575.15 & 1172.78 \\
\hline R-sq & 0.3195 & 0.3310 & 0.3322 & 0.3832 & 0.3168 & 0.2204 \\
\hline
\end{tabular}

Note: The figures in the brackets are white-t statistic, and the paper has considered the problem of heteroscedasticity; ${ }^{* * *},{ }^{* *},{ }^{*}$ denote significant at the $0.01,0.05$ and 0.10 level. 
previous results. The three hypotheses are still supported.

There may be big differences between listed and nonlisted samples, thus in order to better reveals the impact of the liquidity expectation on the credit rating we distinguish the listed and non-listed samples and respectively conduct regression in the Model 11 and Model 12. We control the influences of the financial risk (Intercover and Lev), the corporations' fundamental characteristics (Size and Age), the feature of the securities (Guarantee and IndSup), the macro-economic cycle (GDPgrow), the ownership characteristics (State, V and Deviation), the accounting information quality (Big4 and Top10), and the rating agencies (the Emirates International Credit Rating Co. (EICR), Ltd., the Integrity of the International Credit Rating Co. (IICR), Ltd., Joint Credit Rating Co. (JCR), Ltd. and Shanghai New Century Ratings Co., Ltd. (SHNCR)) on credit rating. There exist differences on the financing ability between listed companies and non-listed companies, but both of them' financing ability (ROE) are significantly positive with the credit rating, which supports hypothesis 1 . The coefficients of the liquidity expectation (CPI) are significantly negative in Model 11 and Model 12 , which supports the hypothesis 2 . The coefficient of CPI $\times$ ROE is significantly negative, meaning that the poor liquidity expectation can reduce the positive impact of the financing ability on the credit rating, so it supports the hypothesis 3 .

In the analysis above, the credit ratings are divided into three levels by the major categories (AAA, AA and A levels), but the AAA level includes AAA and AAA-, the AA can be divided into $\mathrm{AA}+, \mathrm{AA}$ and $\mathrm{AA}-$, and the $\mathrm{A}$ includes $\mathrm{A}+\mathrm{A}, \mathrm{A}-$ and two $\mathrm{BBB}+$, there may be some differences among the same general category, so this paper uses more detailed ratings for the explanatory variables in Model 13. We assigned 0 to the lowest rating $\mathrm{BBB}^{+}$, and assigned 8 to the most senior rating AAA. The regression model is still the ordered Logit model. The results showed that only the coefficient of CPI $\times$ List is negative but not significant, the signs of other variables are consistent with previous. In summary, the results in Table 6 further support our three hypotheses.

The coefficient of the ownership property (State) is significantly positive in the above regression analysis, meaning that state-owned enterprises have a distinct advantage than non-state-owned enterprises on credit rating and that probably because of the difference of the two types of companies on the financing ability. To learn more about the impact of the state-owned enterprises and non stateowned enterprises' financing ability on the credit rating, and how the liquidity expectation influences these two types of companies, we distinguishes the state samples and nonstate samples respectively. To be succinct, we don't show the result in text.

In the regression for state samples, the coefficient of the
List is not significant, that means for the state-owned enterprises, whether listed or not has no significant influence on the credit rating. Many group companies have good qualification, but they are not listed. Listed or not can't be fully representative for the financing ability of the stateowned enterprises. The coefficient of ROE is significantly positive, that means the higher the profitability of the enterprises, the stronger the financing ability, the higher the issuer credit ratings. The coefficient of the CPI is negative, but not significantly, indicating that the poor liquidity expectation doesn't have significant effect on the stateowned enterprises, the explanation is that the large stateowned enterprises can still get loan from the banks or raise funds on the capital markets. Although the coefficient of CPI $\times$ List is negative, it isn't significant. The implication of that the tightened monetary policy has little impact on the financing ability of the state-owned enterprises whether they are listed or not. While the coefficient of $\mathrm{CPI} \times \mathrm{ROE}$ is significantly negative, and that reveals the liquidity expectation will affect the positive impact of the financing ability on the credit rating which characterized by the profitability. In short, the regression of the state samples shows that the financing ability can increase the credit rating, and the liquidity expectation has a certain influence on the credit rating, but it is relatively limited.

In the regression for non-state samples, the coefficient of List is significantly positive, that shows for non-state corporations only the listed enterprises can solve the problem of financing very well and improve their financing ability, thereby enhancing the bond the principal rating. The coefficient of ROE is positive, but it isn't significant. The coefficient of CPI is significantly negative, that is, the impact of the liquidity expectation for the non-stateowned enterprises is very obvious, when the liquidity expected to shrink, the non-state-owned enterprises are first to be influenced, the financing ability of them will be inhibited and the credit ratings of the non-state enterprises will be lowered, which is shown by the significantly negative coefficients of CPI $\times$ List and CPI $\times$ ROE. In short, the regression of the non-state samples shows that the liquidity expectation has great impact on the credit rating of the non-state enterprises. The main reason is that the financing channels of non-state-owned enterprises are relatively narrow; the financing ability of the non-listed and non-state-owned enterprises is even lower, so much lower for the issuer's credit rating.

\section{Conclusions}

From 2005 to 2007, the global economy was in boom. While the subprime mortgage crisis that broke out in the end of 2007 made the global economy fell into recession from 2008 until now, and it even become worse. However, during this period, the main rating of the issuing enterprises on China's short-term financing bills market presents the 
opposite trend. That is when the market and the economy upsurge, the bond principal rating is relatively poor; when the market and economy downturn, the bond principal rating is relatively high. In other words, the ratings of shortterm financing bills show a counter-cyclical phenomenon.

This paper proposes a theoretical explanation for this phenomenon. That is the liquidity hypothesis. During the period of economic prosperity, market liquidity and capital is relatively abundant, therefore even the companies with poor ratings have access to gain funds. When the market downturns, liquidity is poor, and there are not enough funds on the market, the companies with poor main rating may fall to finance due to the lack of access to funds. Therefore, the liquidity of the market causes the bond rating shows the counter-cyclical phenomenon. The empirical research supports this hypothesis. Thus, when the liquidity expectation is bad, the credit rating of corporations will be lowered. Even the enterprises with strong financing ability, its credit rating will be impacted by the negative expectation of the liquidity. In addition, the credit rating is also affected by the risk of corporate finance, fundamentals characteristic, the issue characteristics of the bond, the ownership characteristics, the quality of the information, as well as the impact of the rating agencies.

As we know few researches on credit rating in China mentioned the "cyclical phenomenon" and study the relationship between credit rating and macro-economy. Our paper provides some evidences for this field and shows distinguish for China credit rating market from developed markets. Although in our paper we investigate the relationship between credit rating and macro-factors, leaving the credit rating untouched, which may reflect the "cyclical phenomenon” more evidently. Further work should be done on the change of credit rating in the future.

\section{REFERENCES}

[1] W. F. Treacy and M. S. Carey, "Credit Risk Rating at Large US Banks,” Federal Reserve Bulletin, Vol. 84, No. 11, 1998, pp. 897-921.

[2] P. Nickell, W. Perraudin and S. Varotto, "Stability of Rating Transitions," Journal of Banking and Finance, Vol. 24, No. 1-2, 2000, pp. 203-227. doi:10.1016/S0378-4266(99)00057-6

[3] J. Amato and C. Furfine, “Are Credit Ratings Procyclical?” Journal of Banking and Finance, Vol. 28, No. 11, 2004, pp. 2641-2677. doi:10.1016/j.jbankfin.2004.06.005

[4] Y. F. Dong, "The Rare Continuous Downgrade on the Domestic Bond Market-Facing a New Round of Credit Crisis,” First Financial Daily, 11 September 2011.

[5] M. C. Robert, "On the Pricing of Corporate Debt: The Risk Structure of Interest Rates,” Journal of Finance, Vol. 29, No. 2, 1974, pp. 449-470.

[6] E. Jones, S. Mason and E. Rosenfeld, “Contingent Claims Analysis of Corporate Capital Structures: An Empirical
Investigation,” The Journal of Finance, Vol. 39, No. 3, 1984, pp. 611-625.

doi:10.1111/j.1540-6261.1984.tb03649.x

[7] E. I. Altman, “The Success of Business Failure Prediction Models: An International Survey," Journal of Banking and Finance, Vol. 8, No. 2, 1984, pp. 171-198. doi:10.1016/0378-4266(84)90003-7

[8] E. J. Elton, M. J. Gruber, D. Agrawal and C. Mann, "Explaining the Rate Spread on Corporate Bonds," Journal of Finance, Vol. 56, No. 1, 2001, pp. 247-261. doi:10.1111/0022-1082.00324

[9] Y. Jafry and T. Schuermann, "Measurement, Estimation, and Comparison of Credit Migration Matrices," Journal of Banking and Finance, Vol. 28, No. 11, 2004, pp. 26032639. doi:10.1016/j.jbankfin.2004.06.004

[10] E. Altman and H. Rijken, "How Rating Agencies Achieve Rating Stability,” Journal of Banking and Finance, Vol. 28, No. 11, 2004, pp. 2679-2714. doi:10.1016/j.jbankfin.2004.06.006

[11] E. J. Elton, M. J. Gruber, D. Agrawal and C. Mann, "Factors Affecting the Valuation of Corporate Bonds," Journal of Banking \& Finance, Vol. 28, No. 11, 2004, pp. 2747-2767. doi:10.1016/j.jbankfin.2004.06.008

[12] W. Perraudin and A. P. Taylor, "On the Consistency of Ratings and Bond Market Yields,” Journal of Banking and Finance, Vol. 28, No. 11, 2004, pp. 2769-2788. doi:10.1016/j.jbankfin.2004.06.009

[13] A. W. Butler and L. Fauver, "Institutional Environment and Sovereign Credit Ratings," Financial Management, Vol. 35, No. 3, 2006, pp. 53-79. doi:10.1111/j.1755-053X.2006.tb00147.x

[14] K. Carling, T. Jacobson, J. Linde and K. Roszbach, "Corporate Credit Risk Modeling and the Macroeconomy,” Journal of Banking \& Finance, Vol. 31, No. 3, 2007, pp. 845-868. doi:10.1016/j.jbankfin.2006.06.012

[15] Q. Liang, “The Comparison of the Western Securities Rating System and Its Implications for China,” Securities Market Herald, Vol. 88, No. 11, 1999, pp. 41-44.

[16] Y. Q. He and Z. B. Fang, "The Bond Credit Rating and the Credit Risk," Management Science, Vol. 16, No. 4, 2003, pp. 45-50.

[17] C. Chen and Z. M. Guo, "The Corporate Bond Financing, Financial Risk and the Bond Ratings of China," The Contemporary Finance \& Economics, Vol. 279, No. 2, 2008, pp. 39-48.

[18] P. He and M. Jin, "The Influence of Credit Rating in the Bond Market in China," Journal of Financial Research, Vol. 358, No. 4, 2010, pp. 15-28.

[19] M. G. Yu and H. B. Pan, "The Political Relationship, the Institutional Environment and the Bank Loans of the Private Enterprises," Management World, Vol. 179, No. 8, 2008, pp. 9-21.

[20] D. L. Luo and L. M. Zhen, "The Private Control, Political Relationship and the Corporate Finance Constraints," Financial Research, Vol. 342, No. 12, 2008, pp. 164-178.

[21] C. Chang, G. Liao, X. Yu and Z. Ni, "Information from Relationship Lending: Evidence from Loan Defaults in China,” Working Paper, 2009. 
[22] J. Fan and T. J. Wong, "Do External Auditors Perform a Corporate Governance Role in Emerging Markets? Evidence from East Asia," Journal of Accounting Re- search, Vol. 43, No. 1, 2005, pp. 35-72. doi:10.1111/j.1475-679x.2004.00162.x

[23] S. Zhu, "The Characteristics of Ultimate Controller and the Informativeness of Accounting Earnings," China Accounting and Finance, Vol. 8, No. 3, 2006, pp. 1-29.
[24] S. Zhu and D. L. Xia, “The Accounting Conservatism, Financing Constraints and the Capital Investment of the Listed Companies," Finance and Economics, Vol. 36, No. 6, 2009, pp. 69-79.

[25] R. Cantor and F. Packer, "Differences of Opinion and Selection Bias in the Credit Rating Industry," Journal of Banking \& Finance, Vol. 21, No. 10, 1997, pp. 13951417. doi:10.1016/S0378-4266(97)00024-1 